\title{
Between Money and Love: Work-family Conflict Among Swedish Low-income Single Mothers'
}

I Christine Roman ${ }^{2}$

Professor of Sociology, Örebro University, Department of Sociology, Sweden

\begin{abstract}
Research suggests that single mothers are an increasingly vulnerable group in Scandinavia. Drawing on in-depth interviews, this study takes a closer look at challenges faced by Swedish working-class and low-income single mothers. It explores how working conditions and economic resources influence their access to valued practices, such as the possibility to reconcile paid work and family commitments. It is assumed that discrepancies between mothers' notions of good mothering and their ability to act in accordance with these values give rise to conflicts and dilemmas. Findings show that lack of financial resources and low control over their work situation significantly limited the mothers' possibility to combine various responsibilities and to practice the kind of mothering they preferred. Furthermore, the opening hours of preschools frequently did not match the mothers' working schedules, and they could often not effectively benefit from some of the social rights granted by the Swedish welfare state.
\end{abstract}

\section{KEYWORDS}

Control over work / economic resources / low-income and working-class Swedish single mothers / relative deprivation / structural ambivalence / work-family reconciliation

\section{Introduction}

$\mathrm{t}$ has been noted that the kinds of state support that single mothers receive can be used as a measure of the position of women more generally (Hobson, 1994, p. 176). The Nordic countries, where family policies emphasize both gender equality and equality in children's living conditions regardless of family form, are frequently cited as good examples. Universal publicly financed childcare has enabled single mothers to support themselves and their children by taking up paid jobs. This in turn has kept poverty rates down (Esping-Anderson, 2016, p. 82; Meagher \& Szebehely, 2012, pp. 98-102). Surprisingly, little is known, however, about how single mothers cope with being both primary breadwinners and carers. Survey data indicate that work-family conflict and financial stress are the strongest predictors of subjective well-being for single mothers in Scandinavia (Bull \& Mettelmark, 2009), but research on work-family reconciliation has mostly focused on dual-earner families. This is also the case internationally (Ciabattari, 2007; Gibson, 2012; Kröger, 2009).

The present study adds to previous research by exploring work-family reconciliation among low-income and working-class single mothers in Sweden. ${ }^{1}$ It is particularly warranted to focus on low-income and working-class single mothers because international

\footnotetext{
${ }^{1}$ You can find this text and its DOI at https://tidsskrift.dk/njwls/index.

${ }^{2}$ E-mail: Christine.roman@oru.se.

Dep. of Sociology, HumUS, Örebro universitet, 70182 Örebro
} 
studies about single mothers' possibilities to reconcile paid work with caring responsibilities have largely focused on middle-class women (Rowlingson \& McKay, 2005). Moreover, as inequalities have increased in the Nordic countries (Kvist et al., 2012), single mothers have become an increasingly vulnerable group (e.g., Skevik, 2006). ${ }^{2}$ Danish researchers even warn that marginalized single mothers will soon constitute a 'postmodern underclass in Scandinavia' (Polakow et al., 2001, p. 4).

This article focuses, in particular, on the ways in which inconvenient working hours, unpredictable working hours, and low income influence single mothers' possibilities to reconcile paid work with caring responsibilities. The role of social networks, and mothers' struggles to be 'good' parents are also discussed. This study shows that the mothers' lack of financial resources and low control over their work situation significantly limited the possibility to combine various responsibilities and practice the kind of mothering they preferred. Furthermore, the opening hours of preschools frequently did not match the mothers' working schedules and they often could not make effective use of some of the social rights granted by the Swedish welfare state.

The following three sections describe the Swedish context, the theoretical framework, and the research design of this study, respectively. The findings are then presented in the fifth section, followed by a concluding discussion, which also contains a brief comparison between low-income working-class single mothers and middle-class single mothers.

\section{The Swedish context}

Single-mother households make up 20\% of all families with children in Sweden. This number has been fairly constant since the 1980s (Lassbo, 1994; Welfare, 2010). Employment rates are high among Swedish single mothers. In Sweden, all mothers are expected to take up employment (Fritzell, 2011, p. 8), and in fact, single mothers work full-time to a larger degree than partnered mothers (SOU, 2011:51, pp. 115, 571).

Several measures have been developed to help all working parents reconcile employment and childcare, including a generous parental leave system, which comprises temporary leave to be taken when children are sick (with reimbursement of almost $80 \%$ of the income before the child's birth), the right to a 6-hour working day when children are under the age of nine (pay being reduced accordingly), and publically financed highquality childcare services (Duvander et al., 2015). Swedish municipalities are obliged to provide childcare for preschool children and schoolchildren up to 13 years. Approximately nine out of 10 Swedish children between 1 and 5 years of age are in licensed childcare. They spend on average about 32 hours a week at the childcare center (The Swedish National Agency for Education, 2007). The measures described obviously facilitate single mothers' work-family reconciliation, as they can leave their children at preschool when working, stay at home with a sick child, and reduce their working hours when children are young. It will become clear, however, that it is not always possible for single mothers to effectively benefit from these rights.

Another pillar in Swedish family policy is the economic transfer system. It is constituted by the provision of a universal child allowance, a means-tested housing allowance (of which single mothers are the largest beneficiary group) and support to single mothers from the Social Insurance Agency when the fathers are not able to pay child maintenance (Duvander et al., 2015, p. 58). Need-based social assistance schemes are also available.

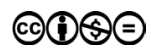


Poverty rates are nevertheless much higher among Swedish single mothers than among dual-earner families. The income gap has widened since the 1990s economic recession. Hence, the proportion of single-parent households with a low economic standard more than doubled between the mid-1990s and 2006 (from 13\% to $29 \%$ of all single-parent households) (Social Insurance Report, 2009:4). Nearly three out of 10 single mothers in Sweden have an income level that is below $60 \%$ of the median in the country (the EU's at-risk-of-poverty measure) (SOU, 2011:51, p. 117). Approximately half of all single mothers have difficulty making ends meet, and one-fifth depend on public assistance (Social Insurance Report, 2010:10, p. 7; SOU 2011:51, pp. 100-101, 118-120; Stranz \& Wiklund, 2011, p. 43; The National Board of Health and Welfare, 2013: 20).

Even though many Swedish single mothers face a difficult financial situation, the variation between single mothers from different socioeconomic backgrounds is large. Mothers with a lower education are particularly vulnerable. Furthermore, statistics suggest that the economic gap between single mothers with more or less education is increasing (Social Insurance Report, 2009:4, pp. 5-6). While single mothers' economic situation on an aggregate level is well researched, few studies have explored low-income and working-class single mothers' possibilities to reconcile paid work and family (this topic is, at least partly, addressed in Björnberg, 1997; Gardberg Morner, 2003; Yazdanpanah, 2008).

\section{Theoretical framework}

Studies about the reconciliation of paid work and family responsibilities are an important background for the present study. Much of this research highlights conflicts between working life and family life (Drobnic, 2011). Typically, paid work and family are seen as two incompatible domains. Conflict is assumed to arise when the individuals' resources are not sufficient to meet demands in both domains (Bianchi \& Milkie, 2010; Eby et al., 2005; Greenhaus \& Beutell, 1985). Conflict thus arises from both working life and family life, though studies indicate that expectations from the former domain are what usually generate conflict (Allan et al., 2007; Byron, 2005; Frone et al., 1992). Research has also revealed, however, that family-related expectations are particularly trying for mothers (Hochschild, 1997). Gender has thus been pointed out as a central factor. Mothers generally report higher levels of conflict than fathers (Bianchis \& Milkies, 2010; Michel et al., 2011; Öun, 2012).

Studies of work-family reconciliation have emphasized time famine and strain as significant sources of conflict (Greenhaus \& Beutell, 1985). Research on single mothers shows that they experience time and strain-based conflict in a similar way as partnered mothers, even if levels of conflict tend to be higher (Albelda et al., 2004; Christopher, 2004; Gill \& Davidson, 2001; Minnotte, 2012). Culturally shaped ethical ideas about the right and proper way to parent/mother are also important contributors (cf. BlairLoy, 2001; Duncan \& Edwards, 1997; Hennessey, 2009; Sayer, 2005). Work-family reconciliation is thus not solely about juggling time and coping. The possibilities to act in accordance with notions of 'good' parenting are also part of the picture.

The main finding in this study is that conflicts and dilemmas arise when there is a discrepancy between the culturally shaped ideal of a good mother and mothers opportunities to act as such. I use the concept of 'structural ambivalence' to understand and 
explain this finding. The concept of 'structural ambivalence' was first advanced by Merton and Barber (1963), and later used in research on family relations by Connidis and McMullin (2002) and Hillcoat-Nallètamby and Phillips (2011), among others. ${ }^{3}$ There are several types of structural ambivalence, but one in particular is relevant for the present study. This type is found in 'the disjunction between culturally prescribed aspirations and socially structured avenues for realizing these aspirations ... It turns up when cultural values are internalized by those whose position in the social structure does not give them access to act in accordance with the values they have been taught to prize' (Merton \& Barber, 1963, p. 98). This conflict thus emanates from mothers' position in the social structure. The concept of 'structural ambivalence' is used as a link between social structure and individual action (cf. Connidis \& McMullin, 2002; Merton \& Barber, 1963, p. 98). It becomes manifest in the lives of mothers when the opportunity structure prevents them from fulfilling (internalized) cultural norms associated with mothering. According to this view, structural contradictions 'become real only through social actors who make decisions about and negotiate courses of action' (Connidis \& McMullin, 2002, p. 563). Mothers are thus seen as actors whose behavior is guided by cultural ideas about the right and proper way to be a mother and who exert agency when dealing with structural ambivalence. The analysis in this paper focuses, in particular, on how access to economic resources and control over work influence the possibility for mothers to act in accordance with their ethical notions 'good' mothering.

\section{The study}

This paper explores work-family reconciliation by focusing on the consequences of limited control over work and access to economic resources, including mothers' possibility to act in accordance with their ethical ideals about good mothering. It is part of a larger research project that aims to improve our understanding of how different kinds of resources influence the possibility for single mothers to combine paid work and caring responsibilities. By control over work is meant the degree to which the mothers could decide when, where, and how much to work (cf. Moen et al., 2013). Access to economic resources refers to income.

To take a closer look at single mothers' own understandings and experiences, and the social context in which these are shaped, 39 relatively open thematic interviews were carried out with Swedish single mothers (cf. Mason, 2002). The term 'single mother' is understood as referring to a mother who has a dependent child up to 18 years of age who is bringing up the child without a resident partner. One important objective of this study was to avoid the middle-class bias common in family studies. It therefore specifically aimed at reaching both working-class and middle-class single mothers. Various channels were used to contact the mothers, including NGOs, preschools, unions, and a website for parents. A semi-structured interview guide was used, covering themes relating to paid work, caring, work-family reconciliation, etc. The interviews lasted around 2 hours on average and were transcribed verbatim. The mothers were given the opportunity to approve and comment on the transcribed interviews. The Regional Ethical Review Board has approved the study.

Interviews were carried out with single mothers from different socioeconomic backgrounds, including highly educated professionals and less educated working-class 
mothers. Interviews with low-income mothers (below approx. 2300 Euro/month) employed in working-class occupations were selected for the analysis in this paper. Workfamily reconciliation among the middle-class mothers is discussed elsewhere (Alsarve et al., 2016). The working-class mothers were mostly employed in female-dominated occupations such as assistant nurses, cleaners, restaurant workers, and assistant preschool carers. Many worked evenings and/or weekends. A few worked nights. Several had temporary or hourly employment contracts. This reflects the fact that nonstandard hours, involuntary part-time, insecure employment, and low earnings are very common among Swedish working-class women (Bergold \& Vedin, 2015). In addition to working, some of the mothers were studying to obtain formal educational qualifications and improve their employment prospects. In Sweden, student aid consisting of grants and loans is available (for everyone) to make this possible. One mother had lost her job shortly before the interview. The mothers lived in urban and rural areas in various parts of Sweden. Most were divorced or separated. Some had never cohabited with the father of their child. The majority of the mothers and their children had little or no contact with the fathers. In two cases, however, the parents had alternating custody.

A possible motive for the single mothers to participate in this study could be the experience of (unusually) high levels of work-family conflict. This would not, however, explain the participation of the many middle-class mothers whose experiences differed from those of the working-class mothers (see the concluding discussion). In any case, one of the main objectives of this article is to explore how limited control over work and low income influenced the mothers' possibilities to reconcile paid work and caring responsibilities. Therefore, the question of representability is of less importance.

A thematic analysis (Braun \& Clarke, 2006) was carried out in several steps, starting with notes that were taken immediately after the interviews. The interviews were carefully read through a number of times, and summaries of the interviews were then written. The research software NVivo was used in the coding process. A number of categories and subcategories were constructed (e.g., work-family conflict, type of conflict, coping strategies), themes were identified, and systematic comparisons between the interviewees were made in order to look for patterns in the data. The themes in this article emerged from the data, but theoretical ideas and concepts also played a role in the analysis (e.g., control over work, structural ambivalence) (cf. Layder, 1998). The findings section is structured by the identified themes. Excerpts from the interviews are used to illustrate important mechanisms or typical cases. Some information has been changed to protect the identities of the participating mothers, who have been given assumed names.

\section{Findings}

The low-income and working-class single mothers in this study generally found it very difficult to reconcile paid work and family responsibilities. The analysis reveals that inflexible, physically strenuous jobs, nonstandard working hours, and insecure employment conditions are important explanations of this (cf. Ammons \& Kelly, 2008; Campbell \& Moen, 1992; Dodsons, 2013; Fagan \& Walthery, 2011; Minnotte, 2012). Financial difficulties aggravated conflicts. In the following paragraphs, I will try to show how and why low control over work and limited access to economic resources created dilemmas, conflict, and emotional stress in the everyday lives of the mothers. This is discussed under 
the five headings: inconvenient working hours, unpredictable working hours, parenting on a low income, dependence on social network, and struggling to be a 'good' mother.

\section{Inconvenient working hours}

A couple of the mothers had chosen to work night shifts to get a higher income. Typically, however, the working-class mothers could not choose their working hours. For mothers with preschool children in particular, nonstandard hours often meant huge problems with coordinating different schedules. One reason for this is that few preschools in Sweden are open evenings, nights, or early mornings (The Swedish National Agency for Education, 2013).

The interview with Rakel provides an illustrative example of how inconvenient working hours and involuntary part-time influence the possibility of reconciling paid work and family. Rakel is an assistant nurse in her forties and a mother of three. She worked nonstandard, inflexible hours for a low wage. She sometimes worked split shifts, meaning that her working day was divided into two parts with a several hours break in the middle. These days she would be away from home both morning and evening. Rakel was involuntarily employed on a part-time contract $(0.85$ FTE). Her part-time earnings were not, however, sufficient to support the family. To 'avoid a financial catastrophe', Rakel had managed to get enough extra hours to reach full time.

It was far from easy to reconcile a full-time job, nonstandard hours, and split shifts with caring responsibilities. When asked how she manages to combine the job with caring for her children (aged 11, 15 and 17), she explained that it was indeed difficult.

you never think you've done the right and ... decent thing. Because you feel that you prioritize your work. And you have to do that [to support the family]. So you always feel inadequate. You can never be a good enough mom, so to speak, because you can't take full responsibility. You always have to put some of the responsibility on the children. (Rakel, assistant nurse)

One of the reasons why Rakel felt inadequate was that her work schedule meant that she often had to leave her children alone at home, forcing her to put 'some of the responsibility' on their shoulders. When she worked early shifts, she left home before the children woke up. When she worked nights, the children had already gone to bed when she returned home. On top of that, her physically demanding job made her feel so worn out after a day's work that she would often go to bed before the children did. She was 'too tired to keep going'. Inflexible, nonstandard working hours, combined with the physically demanding job, thus aggravated the conflicts between different commitments.

Rakel had no access to a social support network to help her out. One of her children was old enough to take care of the younger siblings for brief periods, however. Thanks to her, Rakel was able to work long and inconvenient hours. The daughter helped with 'all these things, taking care of the younger ones, accompanying them on the bus, taking care of this and that'. Although Rakel obviously did not feel particularly good about putting too much responsibility on the oldest child, this interview reveals that, as they grow older, children can provide significant help to their mothers (Ridge \& Millar, 2008: 45).

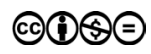




\section{Unpredictable working hours}

Several of the interviewed mothers were temporarily employed, sometimes with nonstandard working hours as well. Some were employed hourly as on-call workers; in other words, they covered for other employees in critical situations. Just as with nonstandard working hours, this type of employment is most common among workingclass women (Aronsson et al., 2002, pp. 153-154, 171; Bergold \& Vedin, 2015, p. 7; Håkansson, 2001, p. 71).

Based on the accounts of single mothers with temporary employment, the following paragraphs aim to portray how this type of employment affected their ability to combine paid work and care for children. Let us begin with Louise, who worked on an hourly basis as a preschool carer. Her employer would call in the morning if they were short of staff. Not knowing whether or when she would work was problematic, according to Louise. For one thing, it caused childcare problems, as some shifts began earlier or finished later than the opening and closing times of her youngest child's preschool. While Louise's colleagues had agreed that she could bring her youngest child to work in the morning if necessary, and take her to preschool when it opened, for the most part Louise depended on her mother and sister being able to turn out on short notice. Other single mothers with on-call employment shared this predicament. They repeatedly had to ask close relatives for help whenever there was a problem with dropping off or picking up their children at preschool, or when their children were sick. This will be discussed at a greater length below.

Income insecurity was another major problem for the mothers employed on an hourly basis. For this reason, they strived to work as many hours as possible. For example, at the time of the interview, Louise, who is quoted above, had been working practically full-time for an extended period. Although she would have liked to work fewer hours to have more time together with her children, she needed 'all the money [she] could get'. Otherwise, she could not make ends meet. Louise made it plain that combining work and family was truly difficult. She found 'everything very stressful' and frequently felt drained of energy.

So I really don't know how to make it work [to combine work and family], but, as I said, you have to [make it work]; you really don't have a choice. There are plenty of times when you feel like: 'I can't go on anymore; to hell with it all, I just can't go on.'. (Louise, on-call preschool carer)

The mothers typically did not want to express feelings of anguish and strain in front of their children. Their efforts to maintain a happy face indicate the existence of a social rule instructing mothers to spare their children from their own feelings of sorrow and grief (cf. Hochschild, 1979). Louise, for example, used to 'cry a bit' alone in the bathroom to avoid displaying difficult feelings. Afterwards, she was ready to keep on going.

As mentioned earlier, Swedish family policy includes the right for parents to stay at home from work if a child is sick (up to 120 days per child annually). The economic compensation for parents who are employed by the hour is typically much lower than the expected earnings that day, however. The reason that they are not fully compensated for loss of earnings when staying at home with a sick child is that the yearly income is the basis of calculation. This was a big problem for the mothers with on-call 
employment. Felicia's situation is instructive in this regard. In addition to studying to become a preschool carer, thereby improving her prospects of getting a permanent job, she worked as an on-call assistant preschool carer. Constantly short of money, Felicia found it difficult to stay at home on the days she had promised to work. Therefore, she sometimes took her son to preschool even though he was sick.

... and [the child] was a bit ill as well, but I felt that I had to work, and I would work until half-past-three, and then I felt like, oh God, okay, I have to do this; he has to be okay, like. So it really is the worst ... I didn't want to become the kind of mother who drops off her child with a runny nose, but I often feel that I have to do that. (Felicia, on-call assistant preschool carer)

Finding themselves in an economically vulnerable position, the mothers were thus occasionally forced to act in ways they did not consider beneficial to the child.

Insecure employment was problematic in other ways. The mothers worried that they would not be hired again if they could not do a shift they had already agreed to. They were afraid of 'being a problem'. The interview with Susanna, a truck driver, is telling. She explained that she would 'do anything' to avoid leaving her employer 'without a driver for a truck'. So occasionally, she took her sick child with her in the truck.

Well, she wasn't that ill in the morning, but when we arrived at the town, she was wiped out and couldn't walk. I unloaded the goods, and the guy there said, 'You can borrow our car to go and buy some aspirin'. After that, I thought, 'It's not right that she has to experience this'. (Susanna, on-call truck driver)

Bringing her sick child to work engendered feelings of guilt in Susanna, but her fear of not being hired again drove her to do so anyway, a situation that Susanna described in terms of being caught in a trap.

\section{Parenting on a low income}

The above discussion has shown that the mothers' limited access to economic resources intensified conflicts between paid work and family commitments. This section discusses additional ways in which financial difficulties aggravated conflicts. While the low-income single mothers were not poor in an absolute sense, a majority depicted their financial situation as bad or very bad. There was no money for extras, and the mothers lacked the economic resources needed to sustain the same lifestyle as other families. Despite struggling to keep consumption down, they frequently had difficulty making ends meet.

... so then I don't buy any clothes; I wear the same ones as before, and, well, there are a lot of things you have to do without. / ... / You have to be smart. But sometimes it just doesn't add up anyway. (Rose-Marie, cleaner)

Always being short of money was a resented aspect of single motherhood. The mothers worried about not having enough money to cover expenses. This was seen as the 'absolutely worst part' of being a single provider. 
It's really heavy because there's never any money left over. Never, ever, ever. (Elin, on-call assistant preschool carer)

The most difficult aspect of it had to do with the children's well-being (cf. Hjort, 2004, p. 47). The mothers wanted their children to have 'normal childhoods', that is, to get what other Swedish children supposedly get, be it things, leisure activities, or vacations. Having a very tight budget made it difficult to realize this aspiration, however. Not having enough money for short vacations, visits to amusement parks, or organized activities for their children, 'like everyone else', was a source of distress for the mothers.

... the most difficult part is that I really want to give [the child] as much as possible. And I feel so restricted in what I can give him. / ... / I mean not having enough money to go away on a winter vacation, and such, like everybody else. And not being able to afford, well, to give him as much [as other parents]. / ... / Like toys and trips and ... like visiting Skansen [open-air museum and zoo] and that sort of thing. I feel extra pressure because I can't give him all the things that everyone else has ... well, his friends in preschool. So it's a bit tough. (Felicia, on-call preschool carer)

Sometimes schools and preschools made things worse by arranging activities that cost money (trips, excursions, picnics, etc.). This tended to put the mothers in an even more problematic spot because of their tight budget.

The children sometimes made distressing comparisons with other children. The interview with Denise, an office assistant, is a good example of this. When she still was cohabitating with her former partner, the family lived in a house in a residential area. After the separation, Denise and her son moved to a flat in the same area. She did not want him to have to change schools and find new friends. However, the child eventually discovered that his friends had things, and did things, that he could not have or do. According to Denise, this troubled him.

'Mother, why don't we live in our own house? Everyone lives in a house except us. I also want a house' and 'I want that' and 'Why can't I go on a skiing vacation?' and 'All my friend go skiing; why don't we go skiing?’ (Denise, office assistant)

Denise's story highlights the importance for children of not deviating from other children. Not being able to afford a living standard similar to that of her child's friends, Denise eventually decided to move to another housing area (cf. Hooper et al., 2007, p. 29).

One strategy used by the low-income mothers was to try to find alternative ways to acquire things that their children wanted or needed, like buying second hand clothes and things. 'Thank heaven for Tradera' [a second-hand Internet site], exclaimed Susanna the truck driver, when talking about her child outgrowing clothes and shoes. The mothers also borrowed equipment to make it possible for their children to participate in school activities, for example, or asked relatives, friends, and colleagues if they had used things to spare.

I'm not afraid to be given things. And to ask friends, and so on, who have older children if they ... I have asked: 'If you have things your kids have outgrown that still work, I would 
be very happy to take them,' and this has resulted in ... I have a friend who came by with a car loaded with super nice stuff, a brand new bicycle that had never been used. She just said, 'Take it, you're welcome!' (Denise, office assistant)

The concept of 'relative (economic) deprivation' seems appropriate for describing the participating low-income mothers' financial situation. According to Peter Townsend (1979, p. 31), people are relatively economically deprived if they lack the resources to 'participate in the activities which are customary, or at least widely encouraged or approved, in the society to which they belong'. The quote from the interview with Denise above exemplifies that feelings of relative deprivation depend on expectations and social comparison. The discussion above also shows that relative deprivation, which can be seen as an instance of structural ambivalence, fosters feelings of frustration and inadequacy on the individual level (cf. Runciman, 1972, pp. 10-12; Pettigrew 2002, p. 368).

\section{Dependence on social network}

As previously mentioned, social support networks were vital for the mothers' ability to cope (cf. Ciabattari, 2007; Gardberg Morner, 2003, p. 208; Gill \& Davidson, 2001; Kröger, 2010; Millar \& Ridge, 2009; Nelson, 2000). Close relatives, if healthy and living nearby, played a particularly significant role. It was mostly the single mothers' own mothers who acted as the most important secondary caregivers (besides preschool teachers). These grandmothers frequently offered to help when the child was sick or when the preschool schedule did not match the mothers' working hours. Some of the mothers were in practice completely dependent on help from close relatives. Moa, for instance, an assistant nurse who worked night shifts for the better pay, relied entirely on help from her parents. They regularly took care of her child when she worked. Moa explained that 'if they weren't here', she would 'have to quit [her] job', because no public childcare was available nights and evenings where she lived. The situation for Susanna, the temporarily employed truck driver, is also telling. She 'loved her job', but it was problematic for her to take morning shifts because they began before her child's preschool opened.

And sometimes they call me and ask, 'Can you take a truck at five?' And who the heck do you call at half-past-four in the morning? Well, it's poor grandma who has to get up at half-past-four to take care of [my child]. (Susanna, on-call truck driver)

According to Susanna, it would be 'impossible to keep working as a truck driver' without her mother's help.

The single mothers were grateful for the assistance they received from relatives. The downside is that it gave rise to feeling of vulnerability, dependency, and lack of autonomy (cf. Skinner \& Finch, 2006). Receiving extensive help could also create feelings of being indebted. One of the mothers, Rose-Marie, who was employed as a cleaner and received much practical help from her parents, put words to this when explaining that she felt like she was carrying a huge amount of 'gratefulness capital', which had become 'debt capital'.

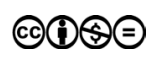




\section{Struggling to be a 'good' mother}

The single mothers who participated in this study considered providing and caring for their children as two important parts of respectable motherhood (cf. Bak, 2003; Björnberg, 1997; Gardberg Morner, 2003, pp. 151-156). They highlighted the importance of having a paid job to support themselves and their children, as well as spending time with their children and meeting their various needs. The above sections reveal that reconciling the different responsibilities was far from easy, however. The mothers found themselves in a situation characterized by structural ambivalence. Limited financial resources and low control over their work restricted the mothers' ability to provide the kind of parenting they considered appropriate. There are plenty of examples of this above. The mothers wanted to 'be there' for their children, stay at home with them when they were sick, pick them up early from preschool, do fun things with them, and so on, but the mothers' working conditions and tight budget severely limited their possibilities to do so. Not having the means to act in ways they considered to be in the best interest of the child engendered feelings of guilt and inadequacy (cf. Scheff, 2000, p. 92). Felicia clearly spelled this out when saying that she 'didn't want to become the kind of mother who drops off her child with a runny nose', but that she had to do exactly that in order to support herself and her son. The challenges confronting the mothers can be described as the money-care dilemma. They needed to earn enough money to provide for the family. To this end, they had to work long hours, leaving them less time and energy to spend on their children. Yasmine who had to work late evenings to make ends meet nicely captures this dilemma.

... on the one hand I want to work more because it means money, but on the other hand I must think of the child, who means even more than that. (Yasmine, restaurant worker and mother of one)

At times, teachers and preschool personnel added to the mothers' bad conscience by communicating cultural parenting ideals that were difficult for the mothers to live up to. For example, they occasionally told mothers that it would benefit the child not to stay too long days in preschool. Isabel, a former cleaner, who for financial reasons worked as an assistant nurse alongside her studies, told these remarks made her feel like a failure as mother. It added 'to [her] already bad conscience' for having to work to 'pay [the] bills'. She felt that the message conveyed that she was considered the kind of 'parent who doesn't act in the interest of the child'. Generally, the expectation that children should not spend long days at preschool complicated the everyday lives of the single mothers. Some mothers frequently asked friends and relatives to pick up the child in order to meet the expectation from preschool teachers. These stories illustrate not only that cultural norms about parenting are negotiated in everyday interaction, but also the role of experts (teachers) in reproducing these norms.

Some Swedish researchers have described the dominating parental ideal in Sweden as 'involved parenthood' (Forsberg, 2009, p. 11; cf. Hays, 1996; Lareau, 2002). According to this cultural norm, both fathers and mothers should make time for and be together with their children. This norm advises parents not only to spend as much time with their children as possible but also to engage with their children's preschool, school, homework, etc. (Forsberg, 2009; Lindgren, 2016). Other researchers emphasize that it 
is mothers, in particular, who are expected to be accessible and close to the child (ElvinNowak \& Thomson, 2001). In any case, the interviews with the single mothers in this study indicate that, at least partly, they had internalized the idea that 'good' parenting means spending a large amount of time with their children. However, in practice, the money-care dilemma meant that these parents had to spend long hours at work, leaving them less time to devote to their children. This discrepancy between the notion of 'good' mothering and the means to attain that goal was a source of conflict that fostered feelings of guilt and inadequacy.

The mothers were far from being passive victims of circumstances, however. They tried to improve their situation and that of their children in several ways. One important day-to-day coping strategy was to carefully plan housework and care tasks such as grocery shopping for the whole week, preparing meals in advance, and so on. This way, the mothers could spend more time with their children when out of work. Turning to their social network for help was also an important strategy that has already been discussed. To make coordination easier, the mothers furthermore negotiated working hours with employers or colleagues.

Also, to make things better in the long run, long-term strategies such as studying alongside working, in order to increase 'employability', were also frequently used (cf. Håkansson \& Isidorsson, 2015, p. 6). Several mothers had changed jobs to get better working hours. Denise, for example, who was employed as an office assistant, used to be employed as a restaurant worker. Working late evenings was impossible to combine with caring responsibilities. She had managed to get a job with convenient working hours. Others, like Isabel who was quoted above, studied in order to improve things in the long run.

\section{Concluding discussion}

This study has explored the ways in which low control over work and limited access to economic resources influence low-income and working-class mothers' possibilities to reconcile paid work and caring tasks in a negative way. The results show that lack of control over work and limited access to economic resources seriously constrained the single mothers' ability to combine paid work and family commitments. It created dilemmas, caused high levels of work-family conflict, and engendered feelings of deprivation and guilt. Low income, in combination with inconvenient and/or unpredictable working hours, split shifts, and insecure employment, thus significantly reduced the mothers' opportunities to be the kind of mother they wished to be (cf. Campbell \& Moen, 1992; Minnotte, 2012). The mothers wanted to 'do the right thing' as mothers, but had to devote much time and energy to paid work in order to cover household expenses. The money-care dilemma meant that it was difficult for them to reduce their working hours to spend more time with their children, to stay at home with a sick child, or to turn down job offers. This structural ambivalence, that is, the discrepancy between the mothers' culturally shaped notions about good mothering (being an involved parent) and the resources available to them to make these ideals come true, fostered feelings of guilt, shame, and inadequacy. Feelings of guilt and shame were thus clearly connected to economic inequality (Sayer, 2005, p. 225). They reduced the well-being of the low-income and working-class single mothers, which is in line with quantitative studies showing 
a correlation between access to economic resources and health among Swedish single mothers (Fritzell, 2011, p. 45; Larsson, 2012, p. 45). This study adds to that research by shedding some light on how this correlation comes about.

The above discussion has furthermore shown that a lack of control over work and limited access to economic resources may in practice reduce the possibility for Swedish low-income and working-class mothers to benefit from some of the rights to which they are entitled. Because of limited household finances, the mothers typically could not make use of their right to reduced working hours. Mothers with on-call employment contracts had difficulty staying at home with a sick child, a problem that was intensified by employment insecurity. On top of this, the opening hours of Swedish preschools frequently did not match the mothers' working schedules. This mismatch meant that mothers were often completely dependent on their social networks.

The working conditions described above are by no means exceptional. There is both a class and a gender dimension to this. To begin with earnings, working-class women employed in female-dominated occupations in the Swedish labor market often work for low wages. There are substantial wage gaps between blue-collar and white-collar workers on the one hand, and between women and men, on the other hand (The Wage Report, 2013). Secondly, working-class women more frequently have physically strenuous jobs and work nonstandard hours (Bergold \& Vedin, 2015, p. 10; Larsson, 2009, pp. 26-32). They seldom have the possibility to use flexitime. Furthermore, split shifts and involuntary part-time employment are widespread in 'female' working-class occupations (Bergold \& Vedin, 2015, p. 8; Larsson, 2009, p. 3; Mårtensson \& Wondmeneh, 2013, pp. 8-16).

How does the situation of the working-class mothers discussed in this article compare to the situation of middle-class mothers who were interviewed in this study? Although this is discussed in greater detail elsewhere (Alsarve et al., 2016), I will make a brief comparison. To begin with, both groups of mothers to some extent shared a similar orientation toward work and family. Having a paid job and being able to support their family was central to all the interviewed mothers, as was the wish to spend much time with the children (cf. Sihto, 2015). Regardless of education and profession, they furthermore experienced stress and a lack of time in their everyday lives. Gendered notions of mothering clashed with the demands of working life. However, the professional middle-class mothers had a considerable degree of control over when and where to perform their work tasks, and thus could adapt their working hours to suit the needs of their children (cf. Hill et al., 2008; Peters et al., 2009). This made scheduling easier, reduced stress, and increased their feeling of control over their everyday lives. This 'employee-friendly' flexibility stands in sharp contrast to the 'employer friendly' flexibility experienced by the working-class mothers (Fleetwood, 2007). In contrast to the low-income mothers, the middle-class mothers in most cases also had the financial resources to reduce their working hours. Many furthermore received considerable financial help from their parents. The parents of the working-class mothers also sometimes helped out in this way, but the sums of money involved were much smaller. A plausible explanation of this, of course, is that the middle-class mothers' parents were in a better position to help their daughters financially (cf. Björnberg \& Ekbrand, 2008, pp. 27-34; Hjort, 2004, p. 48). In this way, the middle-class mothers escaped some of the dilemmas facing the working-class mothers. This highlights the importance of not conceiving of single mothers as a homogenous social category. Differences between the mothers 
were generated in the intersection between gender and class (cf. Rowlingson \& McKay, 2005). At the same time, work demands also created conflicts in the lives of the middleclass mothers. Blurred boundaries between work and family life could engender a feeling that their work was encroaching on their time with their children, and heavy workloads and exacting performance requirements could make it difficult for them to reduce their working hours or to devote themselves exclusively to their children when the latter were sick. However, by and large, they appreciated the great opportunities they had to choose their own working hours and experienced lower levels of work-family conflict.

This study shows that, despite their difficult position, the low-income and workingclass mothers actively tried to improve their situation in different ways (cf. autho; Gardberg Morner, 2003). Perhaps the most important long-term strategy was to improve their employment prospects by studying in addition to working. This way, 'the lump in your stomach' would go away, as one mother phrased it. Studying was considered an investment that would eventually result in better working conditions and more secure employment. The most important day-to-day coping strategy was perhaps to ask social support networks for help. Having access to helping hands made a big difference. Thus, although the Swedish welfare state supplies generous and low-cost licensed childcare, informal care was crucial to combining paid work and family responsibilities (cf. Ciabattari, 2007; Kröger, 2010). Mothers who did not have access to a social support network were especially vulnerable. In particular, the assistance of close relatives relieved pressures in many ways, not least by covering gaps in licensed childcare and helping the mothers when their children were sick. Some mothers had even moved from one town to another in order to be closer to the helping hands of their own parents. The downside of this was that receiving a lot of help meant being reliant on others, which generated a sense of dependency and loss of autonomy.

This study has aimed to lay bare how limited access to economic resources and low control over work influence single mothers' opportunities to reconcile paid work and family commitments. It cannot answer questions about the number of low-income and working-class single mothers that share the same predicaments as the mothers discussed in this article. However, as pointed out earlier, wages and working conditions are strongly related to both class and gender in the Swedish labor market. Workingclass women generally have worse working conditions than other employees, with such things as low wages, temporary employment contracts, physically strenuous jobs, and low control over working hours (Aronsson et al., 2002, pp. 153-154, 171; Bergold \& Vedin, 2015, p. 10; Håkansson, 2001, p. 71). Comparative research in Finland, Norway, and Sweden shows that job, employment, and income insecurity all are related to mental health (Vulkan et al., 2015). The findings in this study reveal the ways in which such working conditions aggravate the conflict between working life and family life, and show that a crucial dimension of this is that they make it difficult to act in accordance with ethical ideals about good mothering. The feelings of insufficiency this causes may be key to understanding the profound negative consequences that problems with integrating paid work and caring commitments can have on individuals' physical and mental health (e.g., Blanch \& Aluja, 2012; Byron, 2005; Mauno et al., 2011). To conclude, the findings of this study not only dispute the rather overoptimistic image of the situation for single mothers in Sweden but also suggest that the trend toward a growing flexibilization of the labor market is likely to increase the structural ambivalence among working-class single mothers.

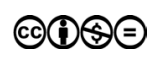




\section{References}

Albelda, R., Himmelweit, S. \& Humphries, J. (2004). The dilemmas of lone motherhood: Key issues for feminist economics, Feminist Economics, 10(2): 1-7. doi: http://dx.doi.org/10.10 $\underline{80 / 1354570042000217694 .}$

Allan, C., Loudoun, R., \& Peetz, D. (2007). Influences on work/non-work conflict, Journal of Sociology, 43(3): 219-239. doi: http://dx.doi.org/10.1177/1440783307080104.

Alsarve, J., Lundqvist, Å. \& Roman, C. (2016). Ensamma mammor. Dilemman, resurser, strategier. [Single Mothers. Dilemmas, resources, strategies.] Lund: Gleerups.

Ammons, S. K. \& Kelly, E. L. (2008). Social class and the experience of work-family conflict during the transition to adulthood, New Directions for Child and Adolescent Development 119: 71-84. doi: http://dx.doi.org/10.1002/cd.210.

Aronsson, G., Gustafsson, K. \& Dallner, M. (2002). Work environment and health in different types of temporary jobs, European Journal of Work and Organizational Psychology, 11(2): 151-171. doi: http://dx.doi.org/10.1080/13594320143000898.

Bak, M. (2003). 'Ensam mor'-familjen [The 'single mother' family] in Bäck-Wiklund, M. \& Johansson, T. (eds.) Nätverksfamiljen, Stockholm: Natur och kultur: 118-143.

Bergold, J.\& Vedin, U. (2015). Tid, makt och pengar. [Time, power and money] Sveriges jämställdhetsbarometer 2015. Stockholm: Landsorganisationen i Sverige 2015.

Bianchi, S. M., \& Milkie, M. A. (2010). Work and family research in the first decade of the 21st century, Journal of Marriage and Family, 72(3): 705-725. doi: http://dx.doi. org/10.1111/j.1741-3737.2010.00.

Björnberg, U. (1997). Single Mothers in Sweden: Supported Workers who Mother, in Duncan, S. \& Edwards, R. (eds.) Single Mothers in an International Context. London: UCL Press: $241-268$.

Björnberg, U. \& Ekbrand, H. (2008). Configuration of family commitments: Patterns of support within kin, in Widmer, E. D. \& Jallinoja, R. (eds.), Beyond the nuclear family: Families in a configurational perspective. Population, Family and Society Volume 9. Bern: Peter Lang: 13-36.

Blair-Loy, M. (2001). Cultural Constructions of Family Schemas: The case of Women Finance Executives, Gender \& Society, 15(5): 687-709.

Blanch, A., \& Aluja, A. (2012). Social support (family and supervisor), work-family conflict, and burnout: Sex differences, Human Relations, 65(7). 811-833. doi: http://dx.doi. org/10.1177/0018726712440471.

Braun, V. \& Clarke, V. (2006). Using thematic analysis in psychology. Qualitative Research in Psychology, 3(2): 77-101. doi: http://dx.doi.org/10.1191/1478088706qp063oa.

Bull, T. \& Mettelmark, M. B. (2009). Work life and mental wellbeing of single and non-single working mothers in Scandinavia, Scandinavian Journal of Public Health, 37(6): 562-568. doi: http://dx.doi.org/10.1177/1403494809340494.

Byron, K. (2005). A meta-analytic review of work-family conflict and its antecedents, Journal of Vocational Behavior, 67(2): 169-198. doi: http://dx.doi.org/10.1016/j. jvb.2004.08.009.

Campbell, M. L. \& Moen, P. (1992). Job-family strain among employed single mothers of preschoolers, Family Relations, 41(2): 205-211. doi: http://dx.doi.org/10.2307/ 584834.

Christopher, K. (2004). Welfare as we [don't] know it: A review and feminist critique of welfare reform research in the United States, Feminist Economics, 10(2): 143-171. doi: http://dx.doi.org/10.1080/135457004200217757.

Ciabattari, T. (2007). Single mothers, social capital, and work-family conflict, Journal of Family Issues, 28(1): 34-59. doi: http://dx.doi.org/10.1177/0192513X06292809. 
Connidis, I. A. \& McMullin, J. A. (2002). Sociological Ambivalence and Family Ties: A Critical Perspective, Journal of Marriage and Family, 64(3): 558-567. doi: http://dx.doi. org/10.1111/j.1741-3737.2002.00558.x.

Drobnic, S. (2011). Introduction: Job Quality and Work-Life Balance in Drobnic, S. \& Guillén, A. M. (eds.) Work-Life Balance in Europe. The Role of Job Quality. Houndsmills, Basingstoke, Hampshire: Palgrave Macmillan: 1-17.

Dodson, L. (2013) Stereotyping Low-Wage Mothers Who Have Work and Family, Journal of Social Issues, 69(2): 257-270. doi: http://dx.doi.org/10.1111/josi.12014.

Duncan, S. \& Edwards, R. (1997). Lone mothers and paid work - rational economic man or gendered moral rationalities?, Feminist Economics, 3(2): 29-61. doi:http://dx.doi. org/10.1080/135457097338690.

Duvander, A.-Z., Ferrarini, T. \& Johansson, M. (2015). 2015:5 Familiepolitik för alla? En ESO-rapport om föräldrapenning och jämställdhet [2015:5 Family policy for everyone? A report on parental benefits and gender equality to the Expert Group on Public Economics]. ESO: Stockholm.

Eby, L. T., Casper, W. J., Lockwood, A., Bordeaux, C., \& Brinley, A. (2005). Work and family research in IO/OB: Content analysis and review of the literature (1980-2002), Journal of Vocational Behavior, 66(1): 124-197. doi: http://dx.doi.org/10.1016/j.jvb.2003.11.003.

Elvin-Nowak, Y. \& Thomsson, H. (2001). Motherhood as idea and practice: A discursive understanding of employed mothers in Sweden. Gender and Society, 15(3): 407-428. doi: http://dx.doi.org/10.1177/089124301015003005.

Esping-Andersen, G. (2016). Families in the 21st Century. Stockholm: SNS förlag.

Fagan C. \& Walthery, P. (2011). Job quality and the perceived work-life balance fit between work hours and personal commitments: A comparison of parents and older workers in Europe, in Drobnic, S. \& Guillén, A. M. (eds.) Work-life balance in Europe: the role of job quality. Basingstoke: Palgrave Macmillan: 69-95.

Fleetwood, S. (2007). Re-thinking work-life balance: editor's introduction. The International Journal of Human Resource Management, 18: 351-359. doi: http://dx.doi. org/10.1080/09585190601165486.

Forsberg, L. (2009). Involved Parenthood: Everyday lives of Swedish middle-class families. Diss. Linköping: Linköping University.

Fritzell, S. (2011). Social differential in health among lone mothers in different policy contexts. Diss. Stockholm: Karolinska Institutet.

Frone, M. R., Russell, M., \& Cooper, M. L. (1992). Antecedents and outcomes of work-family conflict: Testing a model of the work-family interface, Journal of Applied Psychology, 77(1): 65-78. doi: http://dx.doi.org/10.1177/001872679805100203.

Gardberg Morner, C. (2003). Självständigt beroende. Ensamstående mammors försörjningsstrategier. [Autonomous dependency. Single mothers' support strategies] Diss. Göteborg: University of Gothenburg.

Gibson, R. S. (2012). Negotiating the work-family nexus: Examining identity work in the lives of lone parents (unpublished doctoral dissertation). University of Exeter: Exeter.

Gill, S. \& Davidson, M. J. (2001). Problems and pressures facing lone mothers in management and professional occupations - a pilot study, Women in Management Review,16(8): 383-399. doi: http://dx.doi.org/10.1108/EUM0000000006290.

Greenhaus, J. H., \& Beutell, N. J. (1985). Sources of conflict between work and family roles, The Academy of Management Review, 10(1): 76-88. doi: http://dx.doi.org/10.5465/ AMR.1985.4277352.

Hennessy, J. (2009). Morality and work-family conflict in the lives of poor and low-income women, The Sociological Quarterly, 50: 557-580. doi: http://dx.doi.org/10.1111/j.15338525.2009.01156.x. 
Hill, J. E., Grzywacs, J. G., Allen, S., Balnchard, V. L., Matz-Costa, C., Shulkin, S. \& Pitt-Carsouphes, M. (2008). Defining and conceptualizing workplace flexibility. Community, Work \& Family, 11, 149-163. doi: http://dx.doi.org/10.1080/13668800802024678.

Hillcoat-Nallètamby, S. \& Phillips, J. E. (2011) Sociological Ambivalence Revisited, Sociology 45(2): 202-217. doi: http://dx.doi.org/10.1177/0038038510394018.

Hjort, T. (2004). Nödvändighetens pris. Konsumtion och knapphet bland barnfamilier. [The cost of necessity. Consumption and scarcity among families with children] Diss. Lund: Lund Dissertation in Social Work.

Hobson, B. (1994). Solo mothers, social policy regimes and the logics of gender in Sainsbury, D. (ed.) Gendering Welfare States. London: Sage.

Hochschild, A. (1979). Emotion Work, Feeling Rules, and Social Structure, American Journal of Sociology; 83(3): 551-574. doi: http://dx.doi.org/oi/abs/10.1086/227049.

Hochschild, A. (1997). The Time Bind. When Work Becomes Home \& Home Becomes Work. New York: Metropolitan Books.

Hooper, C. A., Gorin, S., Cabral, C. \& Dyson, C. (2007). Living with hardship 24/7: The diverse experiences of families in poverty in England. London: NSPCC/The Frank Butle Trust.

Håkansson, K. (2001). Språngbräda eller segmentering? En longitudinell studie av tidsbegränsat anställda. [Springboard or segmentation? A longitudinal study of short-term employees] Forskningsrapport 2001:1. Stockholm: IFAU - Institutet för arbetsmarknadspolitisk utvärdering.

Håkansson, K. \& Isidorsson, T. (2015). Temporary Agency Workers-Precarious Workers? Nordic Journal of Working Life Studies 5(4): 3-22. doi: http://dx.doi.org/10.19154/ njwls.v5i4.4841.

Kröger, T. (2010). Lone mothers and the puzzles of daily life: do care regimes really matter? International Journal of Social Welfare 19(4): 390-401. doi: http://dx.doi.org/10.1111/ j.1468-2397.2009.00682.x.

Kvist, J., Fritzell, J., Hvinden, B. \& Kangas, O. (2012). Changing Social Equality. The Nordic welfare model in the 21st century. Bristol: Policy Press.

Larsson, J. (2012). Studier i tidsmässig välfärd - med fokus på tidsstrategier och tidspolitik för småbarnsfamiljer. [Studies in temporal welfare - with a focus on time management strategies and politics of time for families with small children] Diss. Göteborg: Göteborg Studies in Sociology.

Larsson, M. (2009). Arbetstider år 2009, Heltids- och deltidsarbete, vanligen arbetad tid och arbetstidens förläggning efter klass och kön år 1990-2009. [Working hours 2009, Fulland part-time work, normally worked time, and scheduling of working hours by class and gender, 1990-2009] Stockholm: LO.

Lassbo, G. (1994). Enförälderfamilj - utvecklingsmiljö. [Single-parent familj - developmental environment] Socialvetenskaplig Tidskrift, 2-3: 130-146.

Layder, D. (1998). Sociological Practice. Linking Theory and Research. London: Sage.

Lindgren, C. (2016). Time for Good Parenthood: A Study of Intercountry Adoption Assessment in Sparrman, A., Westerling, A., Lind, J. \& Dannesboe, K. I. (eds.) Doing Good Parenthood. Basingstoke: Palgrave Macmillan, pp. 17-27.

Lorentzi, U. (2011). Alla andra hämtar tidigt. En undersökning av förskolors öppettider och tider för lämning och hämtning. [Everyone else picks up their kid early. A study of child care centers' opening hours and times for dropping off and picking up] Stockholm: Kommunal.

Mason, J. (2002). Qualitative Researching. Los Angeles: Sage.

Mauno, S., Kinnunen, U. \& Rantanen, M. (2011). Work-family conflict and enrichment and perceived health: Does type of family matter? Family Science 2(1): 1-12. doi: http://dx. doi.org/10.1080/19424620.2011.585908. 
Meagher, G. \& Szebehely, M. (2012). Equality in the social service state: Nordic childcare models in comparative perspective in Kvist, J., Fritzell, J., Hvinden, B. \& Kangas, O. (eds.) Changing Social Equality. The Nordic welfare model in the 21st century. Bristol: Policy Press: 89-119.

Merton, R. K. (1976). Sociological ambivalence and other essays. New York: The Free Press.

Merton, R. K. \& Barber, E. (1963). Sociological Ambivalence, in Teryakian, E. A. (ed.) Sociological Theory, Values, and Socio-cultural Change: Essays in Honor of Pitirim A. Sorokin. New Brunswick: Transaction Publishers: 91-120.

Michel, J. S., Kotrba, L. M., Mitchelson, J. K., Clark, M. A., \& Baltes, B. B. (2011). Antecedents of work-family conflict: A meta-analytic review, Journal of Organizational Behavior, 32(5): 689-725. doi: http://dx.doi.org/10.1002/job.695.

Millar, J. \& Ridge, T. (2009). Relationships of Care: Working Lone Mothers, their children and Employment Sustainability, Journal of Social Policy, (1): 103-121. doi: http://dx.doi. org/10.1017/S0047279408002572.

Minotte, K. L. (2012). Family Structure, Gender, and the Work-Family Interface: Work-to-Family Conflict Among Single and Partnered Parents, Journal of Family and Economic Issues, 33(1): 95-107. doi: http://dx.doi.org/10.1007/s10834-011-9261-4.

Moen, P. Kelly, E. L., Lam, J. (2013). Healthy Work Revisited: Do Changes in Time Strain Predict Well-Being?, Journal of Occupational Health Psychology, 18(2): 157-172. doi: http://dx.doi.org/10.1037/a0031804.

Mårtensson, K. \& Wondmeneh, Y. (2013). Delade turer i välfärdssektorn. Faktaunderlag. [Split shifts in the social welfare sector. Factual data]. Stockholm: Kommunal.

Nelson, M. K. (2006). Single mothers 'do' family, Journal of Marriage and Family, 68(4): 781-795. doi: http://dx.doi.org/10.1111/j.1741-3737.2006.00292.x.

Peters, P., Dulk den, L. \& Lippe van der, T. (2009). The effects of time-spatial flexibility and new working conditions on employees' work-life balance: the Dutch case. Community, Work \& Family, 12: 279-297. doi. http://dx.doi.org/10.1080/13668800902968907.

Pettigrew, T. F. (2002). Summing Up: Relative Deprivation as a Key Social Psychological Concept' in Walker, I. \& Heather, S. J. (eds.) Relative Deprivation. Specification, Development and Integration, Cambridge: Cambridge University Press: 351-373.

Polakow, V., Halskov, T. \& Schultz Jørgensen, P. (2001). Diminished Rights. Danish Lone Mother Families in International Context. Bristol: Policy Press.

Ridge, T. \& Millar, J. (2011). Following families: Working lone-mother families and their children, Social Policy and Administration, 45(1): 85-97. doi: http://dx.doi.org/10.1111/ j.1467-9515.2010.00755.x.

Rowlingson, K. \& McKay, S. (2005). Lone motherhood and socio-economic disadvantage: insights from quantitative and qualitative evidence, Sociological Review 53(1): 30-49. doi: http://dx.doi.org/10.1111/j.1467-954X.

Runciman, W. G. (1972). Relative Deprivation and Social Justice. A study of the attitudes to social inequality in twentieth century England. Harmondsworth, Middlesex, England: Penguin Books Ltd.

Sayer, A. (2005). The moral significance of class. Cambridge: Cambridge University Press.

Scheff, T. (2000). Shame and the Social Bond: A Sociological Theory, Sociological Theory, 18(1): 84-99. doi: http://dx.doi.org/10.1111/0735-2751.00089.

Sihto, T. (2015). Choosing to Work? Mothers Return-to-Work Decisions, Social Class, and the Local Labor Market, Nordic Journal of Working Life Studies 5(3): 23-40. doi: http:// dx.doi.org/10.19154/njwls.v5i3.4805.

Skevik, A. (2006). Lone motherhood in the Nordic countries: sole providers in dual breadwinner regimes, in Ellingsaeter, A. L. \& Leira, A. (eds.) Politicising Parenthood in Scandinavia. Bristol: Policy Press: 241-265. 
Skinner, C. \& Finch, N. (2006). Lone parents and informal childcare: a tax credit childcare subsidy? Social Policy \& Administration, 40(7): 807-823. doi: http://dx.doi.org/10.1111/ j.1467-9515.2006.00534.x.

Social Insurance Report 2009: 4. Ensamstående föräldrars ekonomiska situation. [Single parents' economic situation] Stockholm: Försäkringskassan.

Social Insurance Report 2010:10. Resultatindikatorer för den ekonomiska politiken. [Performance indicators for economic policy] Stockholm: Försäkringskassan.

SOU 2011:51 Fortsatt föräldrar - om ansvar, ekonomi och samarbete för barnets skull. [Parenting after separation - on responsibility, money, and cooperation for the sake of the children].

Stranz, H. \& Wiklund, S. (2011). I välfärdssamhällets marginal - om socialbidragstagande bland ensamstående mödrar av svensk och utländsk härkomst, [In the periphery of the welfare state - dependence on social benefits among single mothers of Swedish and foreign origin] Socialvetenskaplig tidskrift 1: 42-62.

The Swedish National Agency for Education (2007). Barns omsorg 2005. Rapport 307. Skolverket. Stockholm: Fritzes.

The Swedish National Agency for Education (2013). Föräldrars val och inställning till förskola och fritidshem. Resultat från föräldraundersökningen 2012. [Parents' choices and attitudes regarding child care and after-school activities. Results from a survey of parents in 2012] Rapport 392. Skolverket. Stockholm: Fritzes.

The National Board of Health and Welfare 2013, Ekonomisk utsatthet och välfärd bland barn och deras familjer 1968-2010. [Economic vulnerability and welfare among children and their families, 1968-2010] Socialstyrelsen. Underlagsrapport till Barns och ungas hälsa, vård och omsorg 2013. [Child and youth health and welfare report 2013].

The Wage Report 2013, LO. http://www.lo.se/start/lo fakta/lonerapport ar_2013. Lönerapporten 2013 2015-11-20.

Townsend, P. (1979). Poverty in the United Kingdom. A Survey of Household Resources and Standards of Living. Harmondsworth, Middlesex: Penguin Books Ltd.

Welfare, 2010, [Välfärd 2010] No 2. Swedish Statistics.

Vulkan, P., Saloniemi, A., Svalund, J. \& Väisinen, A. (2015). Job Insecurity and Mental Well-Being in Finland, Norway and Sweden, Nordic Journal of Working Life Studies 5(2): 33-53. dcsoi: http://dx.doi.org/10.19154/njwls.v5i2.4792.

Yazdanpanah, S. (2008). Att upprätthålla livet: om lågavlönade ensamstående mödrars försörjning i Sverige. [Making a living: on low-income single mothers' means of support in Sweden] Diss. Stockholm: Stockholms universitet.

Öun, I. (2012). Work-family conflict in the Nordic countries: a comparative analysis, Journal of Comparative Family Studies, 43(2): 165-184.

\section{End notes}

1 This study is funded by the Swedish Research Council (Vetenskapsrådet).

2 Due to an economic boom and low and falling unemployment rates, Norway is an exception (Skevik, 2006, p. 255).

3 The term used by Merton and Barber is 'sociological ambivalence'. 